\title{
Roadside vegetation: estimation and potential for carbon sequestration
}

\author{
Da Silva AM (1), Braga Alves C ${ }^{(1)}$, Alves SH ${ }^{(2)}$
}

The present paper reports the assessment of the vegetation occupancy rate of the roadside, through analysis of aerial photographs. Using such value the potential of these areas to be employed as carbon (C) sinks was also assessed. Moreover, for the areas suitable for afforestation, the potential for carbon sequestration was estimated considering different species of vegetation, both native (scenario 1) and exotic (formed by Pinus sp. and Eucalyptus sp. - scenario 2). The study was carried out through GIS techniques and two regions were considered. A set of equations was used to estimate the rate of occupancy over the study areas, as well as amounts of fixed $C$ under the above scenarios. The average occupancy rate was $0.06 \%$. The simulation showed a higher potential for $\mathrm{C}$ sequestration in scenario 2, being the estimated amounts of $\mathrm{CO}_{2}$ sequestered from the atmosphere per $\mathrm{km}$ of roadside: 131 tons of $\mathrm{CO}_{2} \mathrm{~km}^{-1}$ of highway to native species and 655 tons of $\mathrm{CO}_{2} \mathrm{~km}^{-1}$ of highway for exotic species (over period of 10 years for both estimates). If we consider the whole road network of the São Paulo State (approximately $190000 \mathrm{~km}$ ) and that a considerable part of this road work is suitable to receive this kind of service, it is possible to predict the very high potential for $C$ sequestration if managers and planners consider roadside as area for afforestation.

Keywords: Carbon sequestration, Roadside vegetation, Potential for $C$ sequestration, Afforestation, Forest management

\begin{abstract}
Introduction
One of the most significant challenges of $21^{\text {st }}$ century is reducing the impact of climate change by developing effective ways of adaptation (Mendelsohn \& Dinar 2009). Climate change is the result of increased greenhouse gases (GHG) emissions over the last 150 years, mainly from fossil fuel utilization and high deforestation rates (Bradley et al. 2003, Santi et al. 2007). The mitigation of these changes is essential to avoid future climatically driven catastrophes (PNUD 2008).

One way to mitigate excessive GHG is by promoting carbon (C) sequestration and storage through increasing $\mathrm{C}$ sinks (Gower 2003). It can be difficult to increase existing $\mathrm{C}$ sinks or finding new ones, and it is often expensive.

Roadsides are a land segment that can be
\end{abstract}

(1) Environmental Engineering, Unesp, Campus Sorocaba, SP (Brazil); (2) Codevasf, Brasília, DF (Brazil)

(a), Alexandre Marco da Silva (amsilva@sorocaba.unesp.br)

Received: Mar 11, 2010 - Accepted: Jun 16, 2010

Citation: Da Silva AM, Braga Alves C, Alves $\mathrm{SH}, 2010$. Roadside vegetation: estimation and potential for carbon sequestration. iForest 3: 124-129 [online: 2010-09-27] URL: http://www.sisef.it/iforest/show.php? id $=550$ used as a $\mathrm{C}$ sink, and which may be considered in afforestation activities, as well as in other ecological functions. Roadsides are areas outside the paved or traveled ways (ODOT 2006). Such areas are expropriated by the government to build a highway, and includes, in addition to the road itself, gardens, artwork, and roadside signs. It extends up to the fences that separate the road from adjacent properties (DNIT 2005).

In Brazil, for single lane roads, the roadside vegetation is considered an "area for permanent preservation" of 60 meters width, and 100 meters for double track. Additionally, there is the "no built-up" zone where construction of any kind is prohibited, including urban, suburban, and rural expansion, that spans 15 meters on each side of the roadside, as prescribed in the Brazilian $\mathrm{Fe}$ deral Law no. 6766 of 19 Dec 1979 (DNIT 2005).

According to Brazilian Agency of Terrestrial Transport (ANTT 2006), Brazil has more than 1600000 kilometers of federal and state highways, and São Paulo State has more than $190000 \mathrm{~km}$ (DER 2009). Considering the width of this range and extent of the highway network, there is a huge potential for creating $\mathrm{C}$ sinks (including soils) if these areas were considered for afforestation activities.

Plants sequester and store C. Moreover, forests have the ability to sequester $\mathrm{C}$ for decades, stored in the wood and other orga- nic matter (Perry 1998). The lifetime of a tree can be decades and even centuries, although incremental growth after maturity are generally much lower than those recorded in earlier life-cycle phases.

The faster growth of forest biomass in the tropics, due to higher temperatures and regular rain (Britez et al. 2005, Rezende et al. 2001), constitutes a big advantage in recovering degraded lands with the aim of $\mathrm{C}$ sequestration. In addition, for sequestering and storing $\mathrm{C}$, the presence of forest vegetation in the roadside would bring other benefits, such as:

1.Erosion control/reduction. The revegetation or thickening of vegetation cover results in slowing the rate of runoff, in reducing or avoiding the drag mass of sediment and in the formation of gullies, and in increasing the volume of water retained in the basin (EMBRAPA 2009).

2. Silt reduction. The reduction in sediment yield is directly responsible for a decrease in siltation of water bodies near the replanted area (Coevert-Keesstra et al. 2009).

3. Formation of ecological corridors. Deforestation and fragmentation of vegetation in different neotropical biomes, has produced serious consequences for native biota, due to the drastic reduction of habitat and genetic isolation of populations (Chiarello 1999). In regions where the fragments are close to roads, forming a continuous band of vegetation along these roads can act as a corridor, allowing the flow of animals from one section to another, contributing to the conservation of these populations (Firme 2006).

4. General landscape. The planting of trees and shrubs species gives better visual comfort for road users, providing protection from natural gaps and also minimizing the visual impact of negative aesthetics associated with bordering areas, where landfills, ponds, sewage treatment, industries, etc., may be present (DER 2002).

5. Reducing woodland fire. Human activities are the main cause of fires in tropical forests. These activities, by promoting deforestation and utilizing fire in a disorderly way, create favorable conditions for woodland fires (PAB 2009). In addition, some human behaviors, like throwing away cigarettes butts on the dry herbaceous vegetation on the roadside, may generate fire spots that can spread, and depending on local conditions may become large fires. Forested areas, by decreasing the presence of dry grasses and increasing the local humidity, contribute to in decreasing fire risk. 6. Avoiding urban spread out in inappropriate areas. The implementation of a highway in an urban center promotes serious 


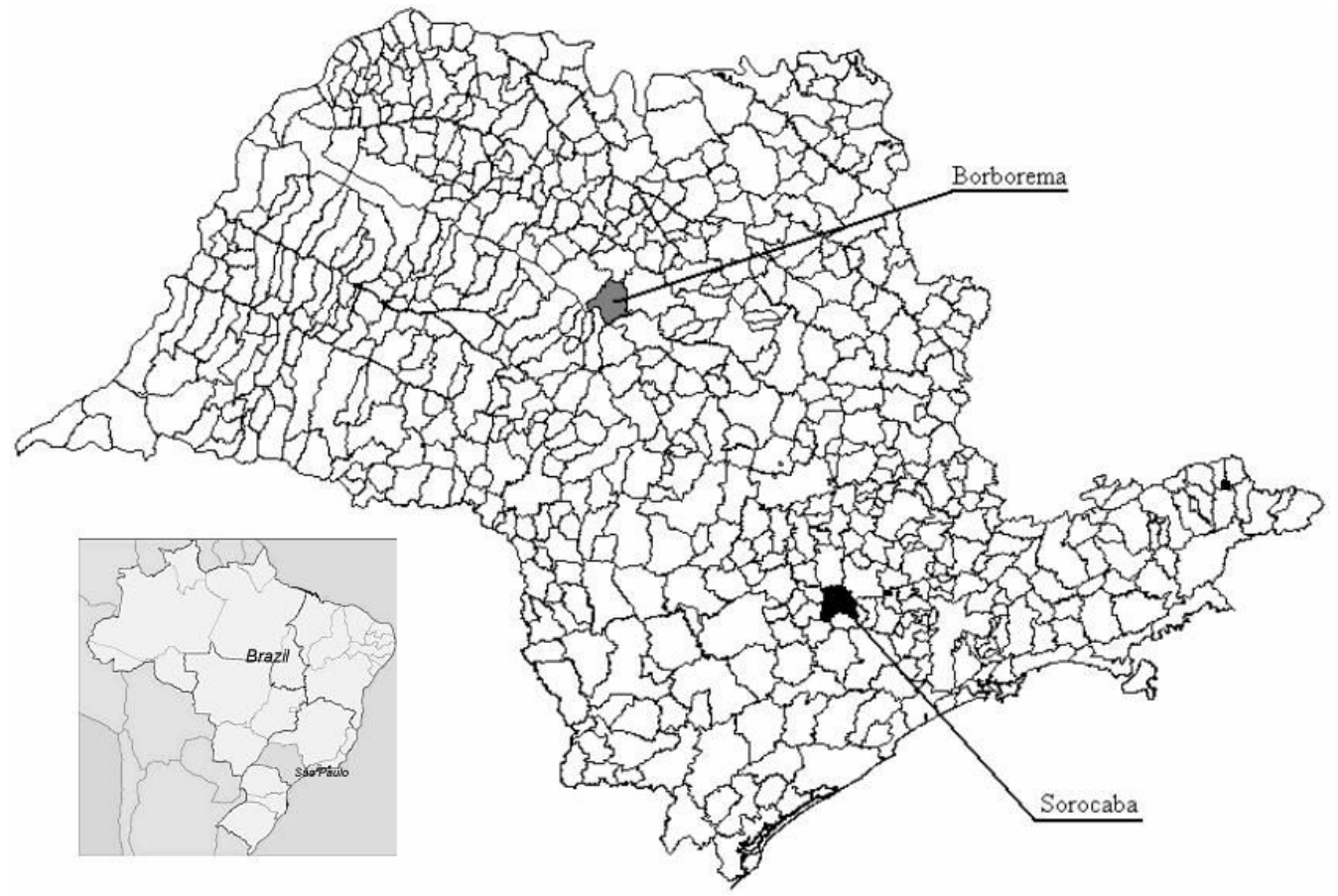

Fig. 1 - Localization of São Paulo State in Brazilian territory (smaller map) and both cities in São Paulo State map.

changes in the land cover such as roadside advertisements and services. Users look at the easy access that it offers (DNIT 2005). The existence of forest vegetation in these areas would prevent or reduce the number of irregular occupancies.

7. Reduction of noise pollution. One of the main issues concerning people who live in areas adjacent to highways is the noise. The noise emitted by vehicles, may cause health problems. Studies carried out by DNIT (2005) show that the noise levels that reach the homes are generally above those recommended by public health care. Forests or plant barriers might act as acoustic insulation, reducing the noise level.

8. Carbon credits. There are several types of projects that can generate $\mathrm{C}$ credits in the voluntary market or the Clean Development Mechanism (CDM), where afforestation and reforestation are known and methodologies for quantification of $\mathrm{C}$ sequestration and subsequent generation of $\mathrm{C}$ credits can be determined. Afforestation projects may mitigate the greenhouse effect through $\mathrm{C}$ capture and fixation in plant biomass, generating multiple benefits. This makes them attractive to an international $\mathrm{C}$ market, because of environmental and economic benefits that are produced (Britez et al. 2005)

9. These facts indicate a viability and success of the proposed project for the generation and sale of $\mathrm{C}$ credits. However, carrying out a project for this purpose would require the formulation of specific methodologies, or determining the adequacy of existing ones, to be developed to meet the $\mathrm{C}$ credit market rules.

10. Thermal comfort. The role that vegetation plays on thermal comfort has been studied by some researchers. Shrubs, herbaceous vegetation, and especially trees, tend to stabilize the temperature and prevent extremes, in contrast to what happens on artificial surfaces. In general, on sunny days, a grassy area can be 5 to $6{ }^{\circ} \mathrm{C}$ less

Tab. 1 - Characteristics of the Borborema and Sorocaba urban areas. Source: IBGE (2010).

\begin{tabular}{lcl}
\hline \multicolumn{1}{c}{ Characteristics } & \multicolumn{1}{c}{ Borborema } & \multicolumn{1}{c}{ Sorocaba } \\
\hline Neighboring Counties & $\begin{array}{l}\text { Novo Horizonte, Itápolis, } \\
\text { Ibitinga e Itajobi }\end{array}$ & $\begin{array}{l}\text { Porto Feliz, Votorantim, } \\
\text { Mairinque, Itu, Araçoiaba da } \\
\text { Serra, Salto de Pirapora and Iperó }\end{array}$ \\
Distance (km) from Capital & 390 & 90 \\
City area $\left(\mathrm{km}^{2}\right)$ & 553 & 449 \\
Population (n inhabitants) & 14376 & 576312 \\
Human density (n. hab. $\left.\mathrm{km}^{-2}\right)$ & $\sim 25$ & $\sim 1263$ \\
Altimetry (m a.s.l.) & 429 & 601 \\
Biome & Atlantic forest & Atlantic forest \\
Climate & Subtropical Aw & Subtropical \\
\hline
\end{tabular}

than areas that are paved or in concrete (Malafaia et al. 2005).

The issue of vegetation along roadsides has been discussed recently in Brazilians organizations, such as National Department of Infra-structure of Transports (DNIT) and São Paulo State's Department of Roads (DERSP). It was the target of the 2007 law project no. 623 , which concerned "afforestation of roadside". There is, however, a lack of specific information in the literature regarding the benefits and problems caused by the presence of vegetation, or concrete data on the occupancy of roadsides (DNIT 2005). For the latter, the few data found deal with the number of commercial shops, without quantification of correspondent area occupied by these buildings along the roadside. So, distinguishing areas able to be forested and the amount of $\mathrm{C}$ that could be stored by afforestation activities is a way to contribute to GHG mitigation and other environmental improvements.

The aim of this study was to evaluate the density of vegetative cover along roadsides for two locations, and to use this data to estimate the potential for these areas to be used as $\mathrm{C}$ sinks. In addition, for areas with significant potential to be afforested, we compared the potential for $\mathrm{C}$ sequestration using different species of vegetation, both native and exotic.

\section{Materials and methods}

Characterization of studied areas

Two areas were studied, one was a stretch of highway SP-280 (Castello Branco Highway) between the 85 and 95 kilometer mar- 


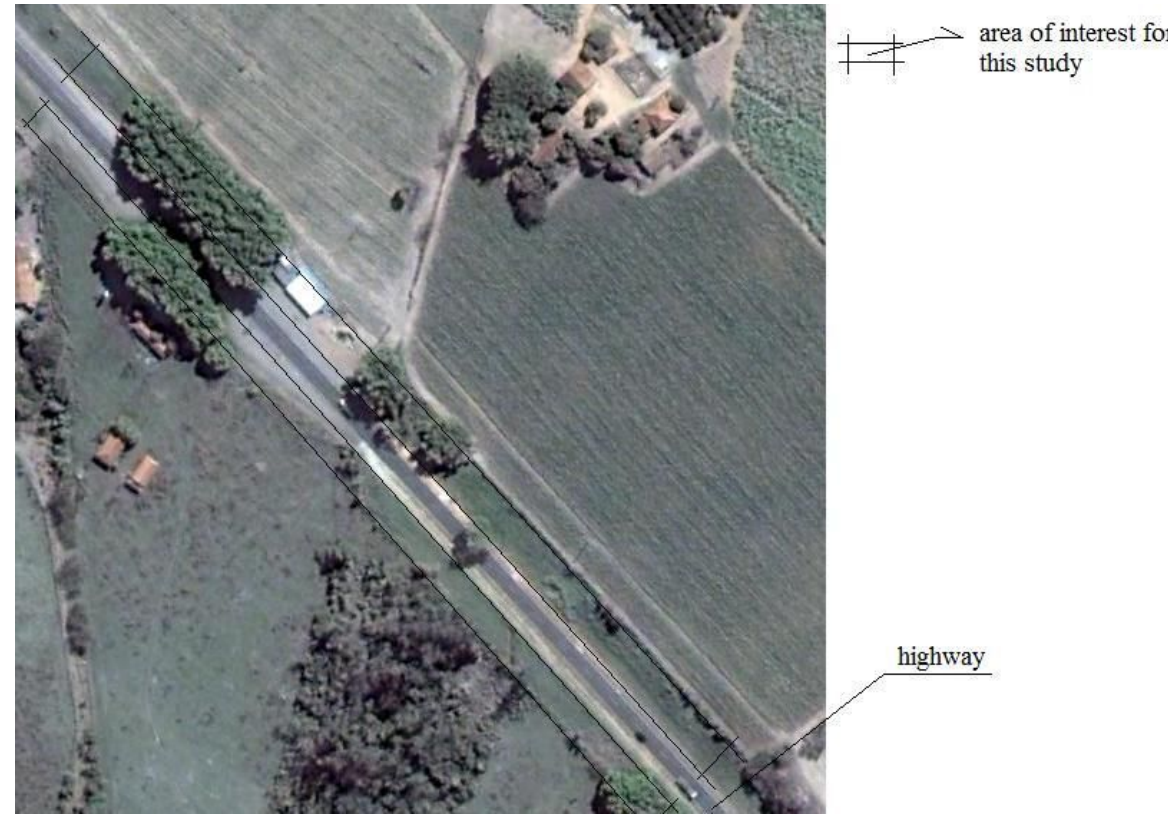

Fig. 2 - Illustration of a stretch of highway of Borborema region (single lane).

kers. The other area was located in the city of Borborema, on highway SP-304 (Highway Deputy Leonidas Pacheco Ferreira) between the 77 and 87 kilometer markers. These areas were selected because they present different kinds of land use and have available updated digital aerial images (Fig. 1, Tab. 1). The land cover of area situated along/around Castello Branco highway presented a strong tendency toward urbanization, mainly due to the proximity of the Sorocaba City. The second area was essentially rural and surrounded by farmland and pastures.

\section{Procedures}

Two sets of aerial photographs were used in this study, both taken in 2006 and available from Escola Superior de Agricultura Luiz de Queiroz - São Paulo University. Photos had 1.0 meter resolution, and were georeferenced, ortho-rectified and mosaiced (Alves \& Alves 2009).

The photos were exported to ArcGIS 9.0 software (ESRI 2004) for visual interpreta-

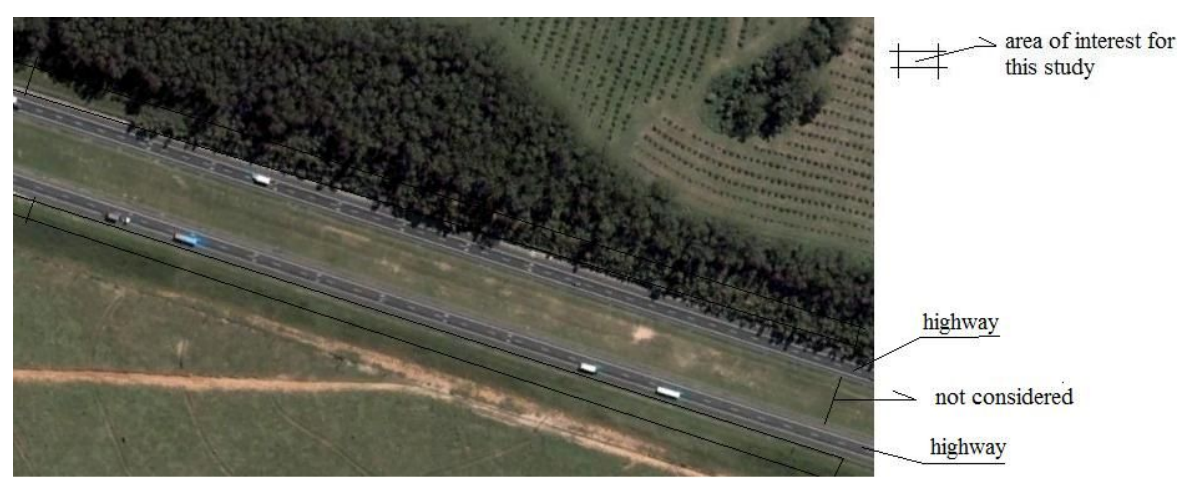

Fig. 3 - Illustration of a stretch of highway of Sorocaba region (two lanes). stretch of single highway (case of Bor-
For comparison, the area between the two lanes of Sorocaba stretch was disregarded, i.e., was not considered the land use through this region (also because among the lanes it is permitted only the grass cover). It was made in order to narrow differences between the two areas of field tracks analyzed.

After, we delimited the beginning and end of the 10 kilometers stretch of land areas in both regions. Subsequently, we analyzed the land cover and classified in the domain area according to one of the three categories listed below:

1. Occupied or non-forested area. This category included buildings, areas of access (ramps), clovers (crossroads) and rivers stretches that are located under bridges. Rivers were included in this category due the impossibility of planting trees over there and consider the areas as well as the potential to act as $\mathrm{C}$ sink;

2. Forested areas. Areas which were already forested within the roadside. The inclusion of this category allowed us to analyze how much of the area would be dismissed of an afforestation activity since it is already in the desired condition.

tion. This visual interpretation was carried out through analysis of features as tones/colors, shapes, patterns/sizes, shadows and textures of the targets (NRCAN 2007). After preliminary examination of photographs of both regions, it was examined two extensions of 10 kilometers of highway, one in each region.

Fig. 2 and Fig. 3 illustrate, respectively, a borema) and a stretch of double highway (case of Sorocaba). Fig. 2 depicts three main situations: constructed areas (white rectangle), forested area and non forested, these last being areas probably suitable for afforestation activities. Fig. 3 presents similar situation and shows a strip that was not considered for computation (between the two lanes).

In the extension located in the region of Sorocaba (SP-280), a two-lane highway stretch was analyzed and in a second one, located in the region of Borborema (SP-304), a single lane highway stretch was analyzed, due to the characteristics of the highways.

3. Afforestation Potential. the term potentially was used in order to consider that areas probably suitable for afforestation activities. However additional studies are suggested in order to detect needs for decontamination of soil, topographic and/or soil (fertility) corrections, and other activities that will collaborate with plant growth and delivery success for activity.

By checking the land cover from photography, we digitalized the polygons according to visual interpretation and after, each polygon was classified according to one of category described above.

Once the study area (roadside) is fifteen meters wide on each side of the road, i.e., (30) meters in total, we considered as total area of the field ranges for each stretch the length times the width analyzed, according to the eqn. 1 (Alves \& Alves 2009):

$$
A_{F D(B, S)}=C \cdot L
$$

where $A_{\mathrm{FDB}}$ is the area of the section of the roadside analyzed - Borborema, $A_{\mathrm{FDS}}$ is the area of the section of the roadside analyzed Sorocaba, $L$ is the width of the roadside, $C$ is the length of the section analyzed.

The occupancy rate of each region was obtained by the following equations (Alves \& Alves 2009 - eqn. 2, eqn. 3):

$$
\begin{aligned}
& O . R_{B}=E_{A B} / A_{F D B} \\
& O \cdot R_{S}=E_{A S} / A_{F D S}
\end{aligned}
$$

where $O . R$. borema, $O . R . \mathrm{s}$ is the occupancy rate of Sorocaba, $E_{\mathrm{AB}}$ is the sum of polygons areas classified as occupied or forested area in Borborema, $E_{\mathrm{AS}}$ is the sum of polygons areas 
classified as occupied or forested area in Sorocaba.

Considering that it was used the same extent of land areas analyzed in two sections, the occupancy rate of the roadside $\left(O . R_{\mathrm{A}}\right)$ was calculated using the average value of the two occupancy rates (eqn. 4).

$$
O \cdot R_{A}=\frac{\left(O \cdot R_{\cdot}+O \cdot R_{\cdot}\right)}{2}
$$

In order to compare the amount of $\mathrm{C}$ stored in the areas of the State of São Paulo, two different scenarios were analyzed, each one covered by a different type of vegetation. The Scenario 1 was constructed considering native species from the Atlantic Rain Forest (Brazilian Southeastern region). Scenario 2 was constructed considering exotic species commonly used in reforestation activities, represented essentially by species of Eucalyptus spp. and Pinus spp., once they are the most commonly species used in reforestation activities in the Brazil (Oliveira 2005).

The estimation of the amount of fixed $\mathrm{C}$ was established considering a period from 2 to 10 years for the two different types of vegetation here considered. This period was established according to bibliographical reference used (Britez et al. 2005) and also to obtain a measure of comparison between the scenarios, once there were no detailed database regarding rates of accumulated $\mathrm{C}$ in the first two years for the first type of vegetation.

The amount of fixed $\mathrm{C}$ by each type of vegetation over the mentioned period was estimated by the average of the increase of $\mathrm{C}$, considering the species studied by Britez et al. (2005). These authors estimated of the amount of fixed $\mathrm{C}$ during the period from two to ten years for each kind of vegetation by average values of $\mathrm{C}$ incremented among all species of native trees considered in the study. This bibliographical reference provides values of storage of $\mathrm{C}$ per year, divided into periods of 2 to 5 years and 5 to 10 years.

Afterwords, in order to calculate the amount of stored $\mathrm{C}$ during the period 2 to 10 years, it was calculated the average accumulated $C$ by all species in each period. Such calculated value was multiplied by the corresponding period. Then, we summed the values obtained for each one of the two mentioned periods, in order to obtain the total increase of $\mathrm{C}$ within the specified period.

The same procedure was carried out for quantifying the accumulation of $\mathrm{C}$ by exotic species and considering the same considered period. Thus, considering whole aboveground biomass, we consider that the amount of accumulated $\mathrm{C}$ was 12.63 tons of $\mathrm{C}$ per hectare for native species and 63.09 tons of $\mathrm{C}$ per hectare for exotic species.

The coefficients of variation computed for the native species, in periods from 2 to 5 years and 5 to 10 years were 1.54 and 1.31 , respectively. For exotic species, the coefficients were 0.56 and 0.36 , respectively. These situations show expressive variation in stored $\mathrm{C}$ between the species used, particularly for native species.

The calculation of total increment of $\mathrm{C}$ was performed by multiplying the content of fixed $\mathrm{C}$ for each scenario of areas considered as not employed. This rate was defined as (1O.R.A), i.e., total area considered for the full domain separately from areas considered inadequates of reforesting. It was estimated the amount of $\mathrm{C}$ to be fixed per kilometer of road, according to eqn. 5 :

$$
C F_{x}=\left(1-O \cdot R_{A}\right) \cdot I C N
$$

where $C F_{\mathrm{x}}$ is the amount of fixed $\mathrm{C}$ in scenario " $\mathrm{x}$ " (tons of $\mathrm{C} \mathrm{ha} \mathrm{C}^{-1}$ ) in the roadside area, according to average occupancy rate, $O . R$. A is the average occupancy rate of the roadside, $I C N$ is the increment of $\mathrm{C}$ in the period from 2 to 10 years of native species (tons of $\mathrm{C} \mathrm{ha}^{-1}$ ) for Scenario 1, or exotic species (Pinus spp. and Eucalipytus spp.) in tons of $\mathrm{C} \mathrm{ha}^{-1}$ for Scenario 2.

In order to demonstrate the potential of study area for incrementing and storing of $\mathrm{C}$, we calculated the amount of $\mathrm{C}$ fixed in both scenarios (natural forest and exotic species) per kilometer of road. For this, it was determined how many meters of road were required to have an amount of one hectare of land areas, considering its width, or 15 meters to each side of the highway, using the following eqn. 6 :

$$
C_{m}=\text { Area }_{h a} / \mathrm{W}
$$

where $C_{\mathrm{m}}$ is the length of road (in meters) for 1 hectare of land areas, Area $_{\text {ha }}=1$ ha area $=$ $10000 \mathrm{~m}^{2}, W$ is the roadside width $(=30 \mathrm{~m})$. So, $C_{\mathrm{m}}=10000 \mathrm{~m}^{2} / 30 \mathrm{~m}=333$ meters.

This means that, approximately for each 0.3 kilometers of highway, we have 1 hectare of land areas. Or, at $1 \mathrm{~km}$ of highway, we have approximately 3 ha of land areas. Based on these calculated values in eqn. 5 and eqn. 6 and using the conversion factor shown above (factor 3 ), it was calculated the amount of fixed $\mathrm{C}$ in the roadside per kilometer of highway through the eqn. 7 :

$$
C F D_{x}=C F_{x} \cdot 3
$$

where $C F D_{\mathrm{x}}$ is the increment of $\mathrm{C}$ in the roadside per $\mathrm{km}$ of highway (tons of $\mathrm{C} \mathrm{km}^{-1}$ ), $C F_{\mathrm{x}}$ is the amount of $\mathrm{C}$ (tons of $\mathrm{C} \mathrm{ha}^{-1}$ ) fixed in scenario " $\mathrm{X}$ " in the roadside.

Considering that one ton of $\mathrm{C}$ equals 3.67 tons of $\mathrm{CO}_{2}$ (Nishi et al. 2005), the proportion of $\mathrm{CO}_{2}$ to be removed from the atmosphere in the two scenarios was calculated by eqn. 8 , both in tons of $\mathrm{CO}_{2} \mathrm{ha}^{-1}$ and in tons of $\mathrm{CO}_{2}$ per kilometer of road (eqn. 8):

$$
\mathrm{CO}_{2} \mathrm{~F}_{x}=\mathrm{CF}_{x} \cdot 3.67
$$

where $\mathrm{CO}_{2} F_{\mathrm{x}}$ is the amount of $\mathrm{CO}_{2}$ fixed from the atmosphere in scenario " $\mathrm{x}$ " (tons of
$\left.\mathrm{CO}_{2} \mathrm{ha}^{-1}\right)$, and $C F_{\mathrm{x}}$ is the amount of fixed $\mathrm{C}$ in scenario " $\mathrm{x}$ " (tons of $\mathrm{CO}_{2} \mathrm{ha}^{-1}$ ).

Finally, for demonstrating the roadside's potential already explored in the areas examined, it was calculated the total area vegetated, and their percentage in relation to the total area with potential for that purpose.

\section{Results and Discussion}

Tab. 2 shows the occupancy rate of each region. For Borborema's region, the sum of areas of polygons belonging to the category occupied or forested area is 1.65 ha and for Sorocaba's region is 1.76 ha.

It was observed that crossroads and ramp highways occupy most of the roadside. Shops, gas stations, motels, hotels, industries, among others, are located outside the range area. However the occupation of the roadside occurs through their access.

It was observed different degrees of urbanization. Consequently, an expressive difference between occupancy rates of the roadside was expected. However, this difference was approximately $6 \%$. This means that, although in most urbanized areas there are a greater number of occupations, in the less urbanized there is a larger number of small farms, culminating in a larger number of interchanges and access to cut the roadside.

It was also found that areas that were included in the category forested areas were located with a wide prevalence in permanent preservation areas (riparian vegetation). These areas are along the rivers that passed under the bridges. In the studied areas (out of permanent preservation areas), only a few trees showed up along the entire stretch, and in the two regions, whose areas were not considered. The estimated value of vegetated area in Borborema was 0.11 ha and in Sorocaba region was 0.05 ha.

Tab. 3 presents the increment of $\mathrm{C}$ estimated for the roadside in São Paulo state with values of $\mathrm{C}$ and $\mathrm{CO}_{2}$ mass expressed in tons per hectare, and rate of tons $\mathrm{CO}_{2}$ per $\mathrm{km}$ in the roadside.

The values, estimated using the average value of increment of $\mathrm{C}$ from the species contained here, present some uncertainties. This is justified by the large difference of fixed $\mathrm{C}$ among different species, as evidenced by the variation index, which reached 1.54. The increment value of one species among all considered for the calculation of increment of $\mathrm{C}$ in Scenario 1, can be moderately different from the average.

Tab. 2 - Occupancy rates for vegetation in the two study areas.

\begin{tabular}{lc}
\hline \multicolumn{1}{c}{ Study Site } & $\begin{array}{c}\text { Occupancy Rate } \\
(\mathbf{\%})\end{array}$ \\
\hline O.R.B - Borborema & 0.055 \\
O.R.s - Sorocaba & 0.059 \\
O.R.A - Mean & 0.057 \\
\hline
\end{tabular}


Tab. 3 - Simulations using both scenarios.

\begin{tabular}{lcc}
\hline \multicolumn{1}{c}{ Parameters } & scenario 1 & scenario 2 \\
\hline $\begin{array}{l}\text { Fixed } \mathrm{C} \text { in the roadside - } \mathrm{CF} \\
\left(\text { tons of } \mathrm{C} \mathrm{ha}^{-1}\right)\end{array}$ & 11.91 & 59.51 \\
$\begin{array}{l}\text { Fixed } \mathrm{C} \text { in the roadside per km of road - CFD } \\
\left(\text { tons of } \mathrm{C} \mathrm{ha}^{-1}\right)\end{array}$ & 35.74 & 178.54 \\
$\begin{array}{l}\text { Amount of } \mathrm{CO}_{2} \text { sequestered from the atmo- } \\
\text { sphere per hectare of roadside - } \mathrm{CO}_{2} \mathrm{~F}\end{array}$ & 43.72 & 218.41 \\
$\left(\right.$ tons of $\left.\mathrm{CO}_{2} \mathrm{ha}^{-1}\right)$ & & \\
$\begin{array}{l}\text { Amount of } \mathrm{CO}_{2} \text { sequestered from the atmo- } \\
\text { sphere per km of roadside - } \mathrm{CO}_{2} \mathrm{FD} \\
\left.\text { (tons } \mathrm{CO}_{2} \mathrm{~km}^{-1}\right)\end{array}$ & 131.18 & 655.24 \\
\hline
\end{tabular}

Forests composed predominantly by exotic species, for this case composed basically by Pinus spp. and Eucalyptus spp., sequester approximately 5 (five) times more $\mathrm{C}$ than that one composed of native species (Britez et al. 2005). Therefore, if the priority criterion for afforestation is exclusively for the mitigation of global warming through $\mathrm{C}$ fixation, the choice of such species could be an alternative, at least in some places. The choice of use of native or exotic specie will be made by managers or decision makers who act over determined place.

Taking into account the occurrence values for the vegetated area, the areas with potential of forestation, and besides of the potential to act as $\mathrm{C}$ sinks, equivalent to 56.71 ha and the average of the vegetated areas two parts is equal to $0.08 \mathrm{ha}$, the use of this potential is, on average, only $0.3 \%$. This shows how far the areas are for an ideal situation of vegetation cover and how much remains to be done in this the area in a specific occupancy (roads).

Finally, we should consider that the database estimated and presented here reflects a typical situation for São Paulo State. São Paulo State is the Brazilian state that encompasses high rates of deforestation and high highway density. Comparing São Paulo State with whole Brazilian territory, we know that Brazil has many differences of land cover and many biomass (Atlantic forest, savanna Cerrado -, Amazon forest, among others) along territory, and the potential for $\mathrm{C}$ sequestration is substantially different along the territory.

So, values regarding the amount of fixed $\mathrm{C}$ by each type of vegetation should be estimated specifically for each region. The method employed here (the sequence of equations) and the potential of use of Pinus spp. and/or Eucalyptus spp. in some localities, is a important subject that should be carefully studied, because such species present excellent adaptations along the Brazilian's environmental conditions (mainly climate and soil) and are genetically engineered. The same should be commented for other regions worldwide, specially regarding the amount of fixed $\mathrm{C}$ by each type

\section{of vegetation.}

It is important mention that the proposal described here does not have the intention of considering forest products generated by trees, as resin, wood, fruits and oil, only the ecological service fixing $C$. Thus, the trees planted in pre-established places would remain there until they dead naturally, even in cases of exotic species. This scenario (Eucalyptus spp. and Pinus spp.) was considered because these species can fix $\mathrm{C}$ more efficiently than many native plant species. However, we understand that this is a second set of benefits that this activity can generate, while the first ones are that ones early described.

\section{Conclusions}

Regardless of urbanization level of the region, there was a large difference between the occupancy rates of the roadside.

We have to consider that if the activity of revegetation prioritizes the avoid future climatically driven catastrophes, it is recommend the use of Pinus spp. and Eucalyptus spp. In relation to the formation of biodiversity corridors and restoration of natural areas, it is recommended the use of native species.

Taking into account the approximate 131 tons of $\mathrm{CO}_{2} \mathrm{~km}^{-1}$ highway to native species, 655 tons of $\mathrm{CO}_{2} \mathrm{~km}^{-1}$ of highway for exotic species and the entire grid road in the State, we can observe that there is an opportunity for a feasibility study for this project in order to generate $\mathrm{C}$ credits.

The tracks represent an area of enormous potential for sequestration and $\mathrm{C}$ storage, and very little of this is explored. Whereas global warming and all the conflicts that revolve and exploited, can contribute significantly to this end.

\section{Acknowledgments}

For the Campus of UNESP Sorocaba, granted by the framework to develop the project. To "Escola Superior de Agricultura Luiz de Queiroz - USP" for available the aerial photography collection for developing the study. To Dr Dianne Stott (National Soil Erosion around this, these areas should be studied
Research Laboratory - West Lafayette, IN, USA) by English revision.

\section{References}

ANTT (2006). Anuário estatístico dos transportes terrestres. Agência nacional de transportes terrestres. [online] URL: http://www.antt.gov.br/ aett/aett_2006/index.htm

Alves CB, Alves SE (2009). Faixas de domínio: estimativa de ocupação e potencial de sequestro de carbono. Monograph (undergraduation in environmental engineering). Universidade estadual paulista Júlio de Mesquita Filho, Sorocaba, SP, Brazil, pp. 21.

Bradley RS, Hughes MK, Diaz HF (2003). Climate in medieval time. Science 17: 404-405. doi: 10.1126/science. 1090372

Britez RM, Borgo M, Tiepolo G, Ferretti A, Calmon M, Higa, RCV (2005). Estoque e incremento de carbono em florestas e povoamentos de espécies arbóreas com ênfase na floresta atl'ntica do sul do Brasil. Colombo, Paranà, Brazil. Embrapa Florestas, pp. 165.

Chiarello AG (1999). Effects of fragmentation of the atlantic forest on mammal communities in south-eastern Brazil. Biological Conservation 89 (1): 71 - 82. - doi: 10.1016/S0006-3207(98) 00130-X

Coevert-Keesstra SD, Dam O, Verstraeten G, Huissteden J (2009). Changing sediment dynamics due to natural reforestation in the Dragonja catchment, S.W. Slovenia. Catena 78: 60 - 71.

DER (2002). Relatório da supervisão de segurança. Departamento de estradas de Rodagem, Minas Gerais, Brazil

DER (2009). Malha viária do estado de São Paulo. Departamento de estradas de Rodagem, Minas Gerais, Brazil. [online] URL: http://www.der.sp. gov.br/malha/estat_malha/malhaRod2009.pdf DNIT (2005). Manual para ordenamento do uso do solo nas faixas de domínio e lindeiras das rodovias federais ( $2^{\text {nd }}$ edn). Departamento Nacional de Infra-Estrutura de Transportes, Diretoria de planejamento e pesquisa, Coordenação geral de estudos e pesquisa. Instituto de pesquisas, Rodoviárias, Rio de Janeiro, Brazil, pp. 106.

EMBRAPA (2009). Formas de controle da erosão linear. Empresa brasileira de pesquisa agropecuaria. [online] URL: http:/www.cnpma.embrapa.br/unidade/index.php3?id=243\&func $=$ unid ESRI (2004). ArcGIS 9.0 - Getting started with ArcGIS. User's manual. Environmental systems research institute, Redlands, CA, USA, pp. 265.

Firme DJ (2006). O papel do setor florestal na formação de corredores ecológicos. Belo Horizonte, Minas Gerais, Brazil.

Gower ST (2003). Patterns and mechanisms of the forest carbon cycle. Annual Review of Environment and Resources 28: 169-204. - doi: 10.1146/annurev.energy.28.050302.105515

IBGE (2010). Brazilian institute for geography and statistics.Cidades@, o Brasil município por município. [online] URL: http://www.ibge.gov.br/cidadesat

Malafaia C, Santos MJO, Slama J (2005). Integração de barreiras acústicas no contexto urbano. 
Maceió. [online] URL: http://www.fag.edu.br/ professores/michele/2008_2/REOFERTA_CONFORTO\%20III/FICHAS/FICHA2.pdf

Mendelsohn R, Dinar A (2009). Land use and climate change interactions. Annual Review of Resource Economics 1: 309 - 332. - doi: 10.1146/ annurev.resource.050708.14424

Nishi MH, Jacovine LAG, Silva ML, Valverde SR, Nogueira HP, Alvarenga AP (2005). Influência dos créditos de carbono na viabilidade financeira de três projetos florestais. Revista Árvore 29 (2): 263 - 270. - doi: 10.1590/S0100 67622005000200009

NRCAN (2007). Natural resources Canada. Air photos 101 - principles of aerial photography. Introduction to air photo interpretation. National air photo library. [online] URL: http://airphotos.nr- can.gc.ca/photos101/photos101_info_e.php ODOT (2006). The Roadside development design manual. Oregon department of transportation. pp. 129. [online] URL: ftp:/ftp.odot.state.or.us/ techserv/Geo-Environmental/Environmental/Procedural\%20Manuals/Roadside\%20 Development Oliveira M (2005). Plantio e exploração do Pinus abre novos mercados e reduz a extração de espécies nativas. FAPESP 115. [online] URL: http://www.revistapesquisa.fapesp.br/?art=2831 $\& b d=1 \& p g=1 \& 1 g$

PAB (2009). Portal ambiente Brasil. Queimadas. [online] URL: http://www.ambientebrasil.com. br/composer.php3?base $=$./florestal/index.html\& conteudo $=. /$ florestal/artigos/queimada.html

Perry DA (1998). The scientific basis of forestry. Annual Review of Ecology and Systematics 29:
435 - 466. - doi: 10.1146/annurev.ecolsys.29.1. 435

PNUD (2008). O desafio climático do século XXI. Programa das nações unidas para o desenvolvimento. [online] URL: http://hdr.undp.org/en/media/HDR_20072008_PT_chapter1.pdf

Rezende D, Merlin S, Santos M (2001). Sequestro de carbono: uma experiência concreta. Instituto Ecológica. Palmas, Tocantins, Brazil.

Santi A, Dalmago GA, Denardin JE (2007). Potencial de sequestro de carbono pela agricultura brasileira e a mitigação do efeito estufa. Passo Fundo, Embrapa Trigo, pp. 8. [online] URL: http://www.cnpt.embrapa.br/biblio/do/p_do78.ht 